\title{
SECOND REPORT TO THE NIUE ISLAND ASSEMBLY ON THE CONSTITUTIONAL DEVELOPMENT OF NIUE
}

\author{
$R Q$ Quentin-Baxter
}

\section{THE GENERAL SITUATION IN NIUE}

In the three years since I first reported to the Assembly, ${ }^{1}$ it has become easier for the people of Niue to feel sure that they understand, and can cope with, questions of constitutional development. Instead of a vague and anxious discussion about the meaning of "self-government", they have been engaged in a programme of practical reforms, designed to give them greater control over their own affairs. This programme - which is reviewed in the next section of the report - is now almost complete, and appears to have been fully accepted. Indeed, the Assembly itself has set the pace of constitutional development, and the Assemblymen have taken their cue from their electors in the villages. After twelve years of debate, the people of Niue need a stable Constitution, based on laws that are already working successfully, and backed by solemn guarantees of New Zealand's continuing interest and support.

In mapping out their own future, the Government and people of Niue face great challenges, but they also have great advantages. Standards of health and medical care are excellent: standards of education are good and getting better. The island has benefited from seasons of ample rainfall without damaging winds. There is a brighter prospect than for a long time past of a strengthened economy, based on the production and processing of limes, in association with cattle raising. Meanwhile, the sale of passion-fruit and of Siratro grass seed, and an improved world price for copra, offer some small rewards to growers. The development of the fruit-processing factory and the construction of a small hotel should help the economy and provide a greater variety and volume of employment.

These modest hopes for the future must be seen against the background of Niue's heavy and continuing dependence on New Zealand's financial aid. It is an irreversible

* Professor of Law, 1968-1984.

1 The first Report was published as [1971] AJHR A4. 
consequence of Niue's association with New Zealand that every Niuean is influenced by New Zealand values, and is accustomed to living standards that the resources of the island cannot sustain. That is one basic reason why the people of Niue have chosen to move towards self-government in continued association with New Zealand. The recently completed three-yearly survey of New Zealand's financial aid to Niue is proof of New Zealand's firm intention to keep up its level of aid to the Island - and especially to encourage measures such as electrification, which can improve the living conditions of the whole community. The United Nations Development Programme is also helping, by providing machinery for Niue's fruit-processing factory. This is a well-chosen gift on a scale that is generous in relation to Niue's population and to more desperate needs in other parts of the world.

Although the most important question for Niue will always be its relationship with New Zealand, the island's connections with other Pacific countries, and with the international organisations which serve those countries, are also important. For twentyfive years, Niue has had the opportunity to express its viewpoint, and to develop its judgment by considering other viewpoints, at meetings of the South Pacific Conference. The advice and facilities offered by the South Pacific Commission, by the regional office of the United Nations agencies, and by the University of the South Pacific, can help to ensure that Niue does not become too dependent on the New Zealand way of doing things, which may not always be well-adjusted to the circumstances of a small community in a tropical island. Because of the comradeship that has developed over the years, Niue is assured, when it attains self-government, of acceptance as a member of the South Pacific Forum, which includes all of the independent or self-governing countries of the region.

Each of these countries, except Australia and New Zealand, became independent or selfgoverning in the lifetime of the United Nations, and in accordance with United Nations principles. It was therefore a significant occasion when, in June 1972, Niue received a United Nations Visiting Mission. The visit dispelled fears and created confidence: it led directly to proposals, made by the Niue Island Assembly on the recommendation of its own Committee on Constitutional Development, to adopt a time-table for the attainment of selfgovernment. In November 1973, the Leader of Government addressed the Fourth Committee of the United Nations General Assembly; and the Committee's resolution, approving the proposals for self-government, won the rare distinction of unanimous approval. The text of the statement made by the Leader of Government to the Fourth Committee will continue to attract notice; for it has the ring of absolute candour.

The final test of any community is not its material resources or the guarantees of outside help: it is the talents of its own people and their willingness to take responsibility. In Niue the machinery of self-government is already complete and at work. The island has its elected leaders. They account for their actions to the Assembly, which conducts its discussions in 
the Niuean language and is heard on radio in every part of the island. The backbone of Niue is its Public Service; and it has been proved many times that Niueans can, on individual merit, achieve the top posts in their own Public Service. So far the island has been fairly successful in keeping the ablest and most qualified of its own people, even though New Zealand can offer them greater material rewards. For example, the Niuean teachers with New Zealand qualifications have, as a group, a fine record of service. By staying in Niue, they have done much more than contribute their skills: they have shown their attachment to the island and their belief in its future. The beautiful new concrete churches in some villages carry the same message: they are built as an expression of faith by people who contribute their money and their labour, and these churches are built to last.

Nevertheless, the tranquil surface of Niuean life conceals a crisis more urgent and relentless than the devastation caused by any hurricane. In ever increasing numbers, the people of Niue are leaving their island, and few of them return. Niueans have always been adventurers, great seamen in the days of sailing ships, founding communities in other parts of Polynesia. Their right to seek their fortunes in New Zealand is as important to them as the guarantee of economic support in Niue itself. The danger to Niue does not lie in the lure of the outside world to those who are restless at home: it lies in a set circumstances which make people feel that emigration is an economic necessity. The movement of people is greatest where the economic pull is strongest. The rewards of traditional agriculture and of unskilled wage labour do not keep pace with the costs of New Zealand tinned foods, landed over the Alofi wharf. The Niuean public servant earns very much less than someone recruited in New Zealand to do the same job; and the difference is widening.

For many years now, locally trained Niuean teachers and nurses, whose qualifications are not recognised in New Zealand, have been joining their unskilled compatriots at work in New Zealand factories. During 1973 alone, the wastage of locally trained Niuean teachers amounted to eighteen. In the schools of Niue some children do not settle to their lessons, because their parents are already in New Zealand and they are to follow when the air fares have been earned. The Niue Public Service has to recruit most of its tradesmen expensively in New Zealand; but those who come to New Zealand from Niue are not eligible for recruitment at New Zealand rates. Of the children sent to New Zealand to learn trades, few do more than discharge their bond, and some do not do that.

In short, there is an imbalance in the results produced by New Zealand's substantial aid to Niue. The people of Niue are entitled to modern air services, and to educational standards approaching those of New Zealand; but, if other aspects of life do not show a corresponding improvement, the air services and the better education will merely serve as a springboard for emigration. To compete with New Zealand conditions, Niueans must have electricity in their homes; but the present supply of electricity to Alofi is under-utilised, because the consumers cannot afford to pay for it. In areas of employment in which Niue 
should be self-sufficient, it must pay New Zealand rates for imported skills, because it has offered so small a reward to its own skilled people. The recommended scale of New Zealand's financial aid to Niue for the years 1974-7 is more generous in its conception than ever before, and it meets almost every request made by the Government of Niue. There is, however, the gravest doubt whether the developments planned can be carried out, in view of the shortage of manpower - and especially of skilled manpower - in Niue.

For a long time, the forces of constitutional development in Niue were paralysed by the people's deep anxiety about their own economic helplessness. If Niue were to choose the box labelled "self-government", what might it find inside? What reason could New Zealand have for suggesting such a choice, unless it were a desire to cast off her own financial responsibility for those New Zealand citizens whose homes were in Niue? What reason could Niuean political leaders have for favouring such a course, unless it were to give them power over their fellow-countrymen - and perhaps to take away from the people of Niue their rights and privileges as New Zealand citizens? For those Niueans who still live in Niue, these dark fears belong to the past. They now know exactly what is in the box labelled "self-government". They have handled the contents, piece by piece; and they can check the pieces off, like items on a shopping list, against the description of the proposed Constitution in the next section of this report.

Even so, some have insisted that an improvement in economic conditions should come before any further constitutional changes. I agree that self-governmnent will not satisfy the people of Niue, unless it is accompanied by an improvement in economic conditions and in social amenities. The last section of this report is devoted to such questions. I have, however, already pointed out that even the most generous measures of assistance can have disruptive, as well as beneficial, effects. New Zealand help cannot make Niue stronger, unless the Government and people of the island are willing to take charge of their own affairs, and to work in partnership with New Zealand. Every change in construction priorities, in wage and salary levels, in incentives to growers, or in the use and development of land raises delicate issues which have to be settled in ways acceptable to the people of Niue. For the New Zealand Government to attempt these tasks would be like trying to mend a wrist watch with one's thumbs.

\section{THE NEW CONSTITUTION}

\section{A Steps to Ensure Consultation with the Niuean People}

The new Constitution, prepared at the request of the Niue Island Assembly, would be annexed to a Niue Constitution Bill. The Assembly would be able to consider both documents before the Bill was passed by the New Zealand Parliament. Moreover, the Niue Constitution Act, and the new draft Constitution, would come into force only when the people of Niue, voting in a referendum observed by the United Nations, had decided that 
they wanted self-government on the basis of this Constitution. Everyone eligible to vote in a general election in Niue would also be eligible to vote in the referendum.

\section{B The Constitution Will Embody Laws Already in Force}

In the referendum, the voters would not be asked to commit themselves to anything strange or untested. The Constitution would embody the system of government which has been brought gradually into force over recent years. The only substantial change - and this has already met with general approval in Niue - would be to enlarge the Niue Island Assembly to include six additional 'common roll' seats. (See Part $\mathrm{N}$ below)

\section{The Niue Constitution Act Will be as Important as the Constitution Itself}

The people of Niue wish to have absolute guarantees that the adoption of the new Constitution will not weaken their relationship with New Zealand. The Niue Constitution Act, which would have the force of law in New Zealand as well as in Niue, must contain these guarantees. It would, in effect, constitute a directive from the New Zealand Parliament to present and future New Zealand Governments. The first matter to consider is, therefore, what guarantees the Assembly should ask for in the Bill which would be introduced in the New Zealand Parliament.

\section{$D$ The Guarantee of New Zealand Citizenship}

The Bill should provide that the people of Niue will continue to be New Zealand citizens. It must follow that they would always be entitled to enter New Zealand freely, and to exercise all the rights of New Zealand citizens while they were in New Zealand. It must also follow that the people of Niue would continue to owe allegiance to the Queen of New Zealand, and to recognise the Governor-General of New Zealand as the Queen's representative. The deeper meaning of this provision is that the people of Niue would be choosing freely to uphold the same basic values as other New Zealanders - a belief in democracy, in the rights of the individual, and in government under law. If this were not so, there could not be a common citizenship and a continuing association between the two countries.

\section{E The Guarantee of Protection}

The Bill should provide that the New Zealand Government will continue to take responsibility for the defence and external relations of Niue. This provision would not reserve any legislative power to the New Zealand Parliament: it would simply be a directive to the agencies of the New Zealand Government to have the same care for the defence and foreign relations of Niue as for those of New Zealand itself. In matters that concerned Niue, or required legislation in Niue, the New Zealand agencies would, of course, act with reference to the laws of Niue and the policies of the Government of Niue, which even now has its own voice in regional affairs. 


\section{F The Guarantee of Economic and Administrative Assistance}

The Bill should contain a guarantee that the Government of New Zealand, acting in consultation with the Goverment of Niue, will continue to provide economic and administrative assistance to Niue. The Niuean people have no illusions about the extent of their economic dependence upon New Zealand, or their continuing need for New Zealand's help in providing expert advice and special skills. Nevertheless, the Governments of New Zealand and of Niue have a common concern to ensure that this dependence does not undermine the self-respect and self-reliance of the Niuean people. The free movement of men and women from Niue to New Zealand cities has strengthened the New Zealand labour force and has weakened the island community. It is therefore equitable that New Zealand's aid to Niue should be on a substantial scale; but, if this aid is to achieve the desired result, it must be planned and administered in a genuine partnership between the Governments of the two countries.

\section{G The New Zealand Representative in Niue}

The Bill should provide that there will be appointed, under the provisions of the appropriate New Zealand legislation a Representative of the New Zealand Government, who will be stationed in Niue. At present, the Resident Commissioner combines two main functions; he is the head of the Niue Public Service; and he also represents the New Zealand Government. The achievement of self-government will require the separation of these two functions; but the people of Niue have made it clear that they regard the presence of a New Zealand Representative as the best evidence of New Zealand's continued interest in Niue.

\section{H The Role of the New Zealand Representative}

It should be stressed that the New Zealand Representative's duties would be varied and challenging. Unlike the Resident Commissioner, he would have no powers under the law of Niue; but his influence would be of great importance in maintaining perfect understanding between the Niue and New Zealand Governments. His perception of the island's needs, and his knowledge of the use being made of existing New Zealand grants, could facilitate the working of the aid programme. He would be responsible for the issue of New Zealand passports and for other matters connected with New Zealand citizenship; and he could be of help in relation to the problems of visitors and of staff recruited overseas. His services would be at the disposal of the Government of Niue in the conduct of its external relations: in particular, he could act as a channel of communication with the offices of regional intergovernmental bodies, and he could assist in the reception of the increasing number of official visitors. 


\section{The Constitution as a Safeguard}

The Niue Island Assembly has, at the present time, very wide powers to add to, repeal, or alter the laws in force in Niue. There are, however, some laws that can be changed only by the New Zealand Parliament, which needs to be satisfied that the people of Niue understand and want the change requested. After self-government the Constitution itself must provide this safeguard. Any rule of law too important to be changed by a majority vote in the Assembly would have to be included or referred to in the Constitution; and the Constitution would provide a procedure for its own amendment. This procedure would also extend to the provisions of the Niue Constitution Act, insofar as they formed part of the law of Niue.

\section{J The Procedure for Amending the Constitution}

The view generally accepted during my consultations in Niue is that a constitutional amendment should not be adopted unless it has received the support of two-thirds of the members voting in the Assembly, and has then been approved by a majority of the electors in a referendum. (Indeed, the Assembly's Committee on Constitutional Development envisaged that the approval of the electors also should be by a two-thirds vote, but it may seem best to apply this very strict requirement only to a few rules which nearly everyone in Niue regards as indispensable: for example, the guaranteed relationship with New Zealand and the independence of the Public Service). The value of the amendment procedure can easily be seen. At present, the New Zealand Parliament needs to be satisfied what the majority of the people of Niue want, before a change is made in the provisions of the Niue Act: under the proposed Constitution the people of Niue would have to vote on such questions in a referendum, before any change could be made.

\section{$K$ Safeguards as to Changes in Other Legislation}

There are some kinds of legislation which, although they cannot conveniently be included in the Constitution, are so important or specialised that they should not be enacted until an expert opinion has been obtained. In particular, it seems desirable to provide in the Constitution that no law creating offences, or providing punishments, or dealing with criminal procedure, or with conditions of imprisonment and probation, shall be passed until a report on the draft legislation has been received by the Assembly from the Chief Justice of the High Court. The same provision might be made, in the case of laws relating to marriage or divorce. Similarly, a report might be required from the State Services Commission in the case of draft legislation affecting conditions of employment in the Niue Public Service; and a report from a specially appointed commission of enquiry could reasonably be demanded before the enactment of any draft legislation relating to the ownership or use of land. These constitutional provisions would not limit the Assembly's powers; but they would ensure that the Assembly acted with knowledge of the implications, and that public opinion could be informed. 


\section{The Niue Island Assembly}

With the coming into force of the proposed Constitution, the New Zealand Parliament would have given up its power to make laws having effect in Niue (though, as a matter of convenience, New Zealand laws could still be applied to Niue at the request and with the consent of the Niue Island Assembly). To have a supreme law-making body is the essence of self-government; yet, in Niue's case, the change is more of form than of substance. The general law of Niue has always been separate and different from the law of New Zealand. Increasingly the New Zealand Parliament has used its powers only to ensure that the laws it passed for Niue were those that the people of the island desired. As the last three paragraphs have explained, the proposed Constitution would offer safeguards at least equal to those which reserved legislation now provides.

\section{$M$ The Present Composition of the Assembly and the Past Performance}

The Assembly is composed of one representative from each of the fourteen villages of Niue. This does not ensure that the vote of each elector is of equal value, or that suitable candidates have an equal chance to gain election; for the villages are widely different in size. On the other hand, the village as a unit is still of great importance to the Niuean people, and there can be no doubt that they regard the equal representation of the villages as the most acceptable basis for their legislature. The proof of the Assembly's authority is in its record. For twelve years it has prescribed the rate of Niue's constitutional progress, not hesitating to resist the recommendations of the New Zealand Government or the urging of the United Nations, if the people were not ready to accept the the change proposed. Yet the Assembly has also shown flexibility, promoting two of its youngest but best-qualified members to the Executive Committee, and requesting further steps towards self-government when the earlier steps had been tested. The timetable for self-government in 1974 was set by the Assembly itself, after it had assessed the impact upon the Niuean people of the United Nations Visiting Mission.

\section{$N$ The Proposed Increase in the Size of the Assembly}

Although the Assembly is accustomed to acting upon the measures proposed by the Executive, it is much less accustomed to asserting its authority over the actions of the executive branch of government. In fact, the Assembly acquired this role only in 1971, when the Resident Commissioner's executive responsibilities passed to the Executive Committee. To help the Assembly perform this new, more active role, it needs strengthening; but that must be done without sacrificing the accepted basis of village representation. The solution which I have suggested - and which seems to be generally acceptable - is that provision should be made for six additional "common roll" seats. Any elector would be eligible to stand for one of these seats; and every elector would have the right to vote for the six candidates of his choice. This arrangement would provide opportunities for candidates, 
whose qualifications were well-known throughout the island, but who might find no vacancy in the representation of their own villages.

\section{O The Future Role of the Assembly}

The Assembly of twenty representatives is quite large in relation to the present population of Niue; but it is not large in relation to the responsibilities of self-government. Moreover, because the island is compact and travel to Alofi is accomplished easily, there is no great cost or difficulty in gathering the Members. The Assembly already has its own Speaker, who will, after self-government, assume the Resident Commissioner's formal responsibility for the summaning of meetings. It seems in every way desirable that the Assembly should retain its practice of meeting at least once monthly, and more often when business demands. Usually, the Speaker will act at the request of the Leader of Government in calling meetings of the Assembly; but the Constitution would provide for other Assembly Members to ask that a meeting be called, if more than six weeks had elapsed since the Assembly last met.

\section{ADDENDUM}

The completion of Professor Quentin-Baxter's second report had to give way to the need to concentrate on drafting the Constitution. The following message to the Leader of Government, dated 4 March 1974, summarises the further matters that Professor QuentinBaxter had intended to cover.

You will now have the introduction to my report and the first half of Part II. The remainder of Part II will deal with the roles of Executive Committee, the Secretary to Government, the Public Service, and the Courts. In general I will be concerned to show that the constitution should embody the laws you already have, and that no-one need regard selfgovernment as a break with the past.

In one particular respect - the role of the State Services Commission - I shall recommend a further modification of the present law. It is agreed by all that we must look to the New Zealand State Services Commission as the guarantee of the freedom of the Niue Public Service from political interference. It is, however, obvious and understandable that the Commission is not in close and continuing touch with the situation in Niue, and that it has to rely on the Maori and Islands Affairs Department for insights into local needs and problems. In the future it cannot do that: the relationship must be strictly the one the law provides between the Commission in Wellington and the authorities in Alofi.

There would therefore appear to be many advantages in having for Niue a special Niue Public Service Commission, the membership of which would be controlled by the New Zealand State Services Commission - though the appointments would be made in consultation with the Executive Committee. This arrangement would safeguard the 
independence of the Niue Public Service and it would allow the State Services Commission's office to handle files and correspondence. The Niue Public Service Commission might include the Chairman and another member of the New Zealand State Services Commission, and - say - two other public servants with special knowledge of Niue.

I shall invite Wellington's comments on this suggestion before I settle the next part of my report. For the moment however, the main point I want to make is that the State Services Commission for Niue - however it is constituted - must play an extraordinarily sensitive role in relation to the well-being of the whole island. Almost everybody in employment is a public servant, and the general level of salary and wages in the Public Service determines how prosperous or impoverished everyone feels. There is virtually no private sector, and such private employment as there is tends to follow rather than lead adjustments to Public Service wage scales.

This situation produces all kinds of curious distortions which have to be corrected if self-government is to succeed. Until now the Executive Committee (and perhaps the senior Public Servants also) have thought that the level of remuneration in the Public Service was purely the Commission's responsibility, and was not a political matter. Meanwhile, the Commission, faced in New Zealand with mounting pressures to raise salaries and unaware of any similar pressures in Niue, has allowed the so-called unified scale to produce an almost intolerable contrast between salary levels for comparable locally engaged and seconded staff.

Emigration from Niue is due to many causes, including a desire for the amentities of city life, a needless worry about the effects of self-government, and the mere fact that the Niueans settled in New Zealand are a magnet which attracts further migrants. In addition to all that, however, is an economic pressure which must be reduced. It is perhaps not too much to say that during the years we have been discussing constitutional development, Niueans have been getting poorer - in the sense that their salaries and wages have not kept pace with the rising prices of New Zealand foodstuffs and other imports, or with the rising levels of remuneration needed to persuade New Zealanders to accept appointments in Niue.

During the same period New Zealand has been aiming to increase its aid to Niue, but as I have suggested in the introductory section of my report, the works programmes which New Zealand is willing to finance are gravely threatened by the lack of manpower to carry them out. It is this series of problems - which hardly affect the wording of the constitution but which can make all the difference to the success or failure of self-government in Niue which have to be treated in the final part of my report. I think that these are also the problems which are worth discussing in some depth with Mr Kirk when he visits Niue.

8. My conclusions will be roughly on these lines: 
(a) The conditions of life in New Zealand and in Niue - including wage levels, taxes and benefits - must always be different, but the association and freedom of movement between the two countries require an effort to ensure that the differences are kept within reasonable bounds.

(b) The continuance of New Zealand's economic aid to Niue should not be regarded simply as a matter of Niue relying on New Zealand's generosity. New Zealand has an investment in the welfare of her own citizens, wherever they live. She also has an investment in the development of healthy and friendly societies in all the countries of the South Pacific.

(c) For a long time isolation preserved the Niuean community. In the future it can be preserved only if economic and social conditions are good enough not to repel the people whose culture and tradition bind them to the island. More and more, we should expect and wish to see able and well-educated Niueans who divide their working lives between their own island and New Zealand or other South Pacific countries.

(d) Probably the economic price of this policy is not high in comparison with the expensive futility of importing more New Zealanders to provide essential services in a community from which most people of working age have departed.

(e) No effort on New Zealand's part will be of much avail unless there can be a genuine partnership between New Zealand and a self-governing Niue. This implies that the Government of Niue will shoulder local problems, including the quite delicate problems of seeing that all sections of the community benefit from New Zealand's economic aid.

(f) As a start there must be both a substantial rise in basic wages and a narrowing of the gap between the remuneration levels of equally well-qualified officers recruited locally and overseas. The consultations which such changes would necessitate should set the pattern for future dealings between the Executive Committee, which has a direct and primary interest in general economic policy, and the State Services Commission.

(g) The New Zealand Government should be asked for its agreement to provide additional economic assistance to cover the cost of changes in salary and wage scales (and this should be a transaction between the two governments, not an adjustment made by the State Services Commission without reference to the Executive Committee).

(h) The features which discourage Niueans with overseas training from returning to their island include poor housing conditions, as well as poor remuneration. The 
New Zealand Government might therefore be asked to finance also a modest programme to increase the supply of pool houses.

(i) The counterpart to these proposals is that the Government of Niue would give attention to the adjustments in taxes and benefits which should accompany a substantial increase in remuneration to almost everyone in employment.

Please treat the foregoing as being only a very rough sketch of parts of the rest of my report. I hope, however, that it will give you a basis for discussion in the Executive Committee and that you can canvass some of the points with other Assemblymen. I shall suggest in a later message the form of resolutions which the Assembly might pass. 